\begin{tabular}{c} 
INDIKATORS Vol 1 (2) (2019) \\
INDIKATORS \\
Journal of Economics and Business \\
http://indicators.iseisemarang.or.id/index.php/jebis \\
\hline
\end{tabular}

\title{
Pengaruh Emiten dan Perilaku Investor Terhadap Keputusan Investor di Pasar Modal
}

\section{Desy Yanti ${ }^{1 \bowtie}$ Mochammad Nugraha Reza Pradana²}

${ }^{1,2}$ Program Studi Manajemen, Fakultas Bisnis, Universitas Universal

\begin{tabular}{|c|c|}
\hline Info Artikel & Abstrak \\
\hline Sejarah Artikel: & $\overline{\text { Saat ini pasar modal merupakan topik pembahasan yang menarik di era globalisasi. Pada tahun } 2017}$ \\
\hline Diterima Mei 2019 & Indeks Harga Saham Gabungan (IHSG) mencapai rekor tertinggi sepanjang masa IHSG ini terkait \\
\hline Disetujui Agustus 2019 & keputusan investor dalam melakukan investasi. Terjadinya peningkatan minat pada dasarnya \\
\hline Dipublikasikan & mencerminkan pertumbuhan ekonomi regional yang lebih kuat, perkembangan pasar modal yang \\
\hline November 2019 & $\begin{array}{l}\text { berkelanjutan, dan peluang-peluang diversifikasi global. Maka penelitian ini dilakukan dengan } \\
\text { bertujuan untuk mengetahui pengaruh kepribadian,sentimen, probabilitas, dan company brand }\end{array}$ \\
\hline Keywords: & dap keputusan investor. Penelitian dilakukan di Kepulauan Riau dengan cara pembagian \\
\hline $\begin{array}{l}\text { Personality, sentiment, } \\
\text { profitability, company }\end{array}$ & $\begin{array}{l}\text { kuisioner secara online, total responden yang terkumpul } 122 \text { responden investor dengan } \\
\text { mengunakan metode analisis regresi berganda dengan mengunakan program Statiscal Package for }\end{array}$ \\
\hline brand, investor decision & $\begin{array}{l}\text { Social Science versi } 19 \text {. Hasil penelitian yang diperoleh adalah sentimen investor dan company brand } \\
\text { merup berpengaruh positif mendukung investor dalam mengambil keputusan investasi. Sedangkan } \\
\text { variabel profitabilitas tidak berpengaruh kepada investor dalam pengambilan keputusan investasi. }\end{array}$ \\
\hline
\end{tabular}

\section{Abstract}

Currently the stock exchange is an interesting topic of discussion in the era of globalization. In 2017 the Composite Stock Price Index (CSPI) reached an all-time high of the CSPI due to investors' decisions in investing. The increase in interest basically reflects stronger regional economic growth, sustainable stock exchange developments, and global diversification opportunities. then this research aims to determine the effect of personality, sentiment, probability, and company brand on investor decisions. The research location at Kepulauan Riau by way of online questionnaires, total respondents collected 122 respondents of investors and using multiple regression analysis using the Statiscal Package for Social Science version 19. The results of the study stating that investor sentiment and brand companies are positive influential factors that support investors in making investment decisions. While the variable profitability does not affect investors in making investment decisions.

\footnotetext{
$\triangle$ Alamat korespondensi:

Komplek Maha Vihara Duta Maitreya, Sungai Panas, Batam

E-mail: yantidesy401@gmail.com
} 


\section{PENDAHULUAN}

Saat ini pasar modal merupakan topik pembahasan yang menarik di era globalisasi. Investasi dan pasar modal telah menjadi bagian dari fundamental ekonomi tidak hanya di Negara maju saja, bahkan juga Negara-negara yang berkembang. Di Indonesia juga muncul dengan kekuatan barunya di sektor investasi dan pasar modal. Perdagangan saham di Bursa Efek Indonesia (BEI). Penilaian berdasarkan pengamatan terhadap fluktuasi Indeks Harga Saham Gabungan (IHSG) di BEI, karena IHSG merefleksikan kinerja BEI secara keseluruhan dan dapat menunjukan bahwa aktivitas investasi di Indonesia mulai tumbuh pesat.

$\mathrm{Hal}$ ini terkait keputusan investor dalam melakukan investasi. Terjadinya peningkatan minat pada dasarnya mencerminkan pertumbuhan ekonomi regional yang lebih kuat, perkembangan pasar modal yang berkelanjutan, dan peluang-peluang diversifikasi global (Ady, Sudarma, Salim, \& Aisyah, 2013; Chang \& Lin, 2015;)

Peningkatan ini menunjukkan perekonominan Indonesia mulai berkembang pesat. Peningkatan IHSG ini terkait dengan keputusan investasi yang dilakukan investor, sehingga yang menjadi sorotan utama adalah proses investor dalam pengambilan keputusan investasinya, seperti hal-hal apa saja yang dipertimbangkan investor dalam pengambilan keputusan investasinya.

Mengingat penelitian sebelumnya (Jalilvand, Rostami, \& Switzer, 2018) "Informed and uninformed investors in Iran" hasil yang didapatkan hanya jenis kelamin, usia, dan budaya sama-sama mempengaruhi kedua tipe investor. Menyatakan variabel sentimen, kepribadian profitabilitas, dan company brand menghasilkan tidak homogen pengaruhnya terhadap keputusan investor. Perilaku investor yang memiliki informasi lebih konsisten dalam pengambilan keputusan dengan rekomendasi umum dari teori ekonomi. Investor yang kurang memiliki informasi dalam mengambil keputusan lebih dipengaruhi oleh perilaku.
Menurut (Brigham \& Houaton, 2001) signal adalah suatu tindakan yang diambil perusahaan untuk memberi petunjuk bagi investor tentang bagaimana manajemen memandang prospek perusahaan. Informasi tersebut penting bagi investor dan pelaku bisnis karena informasi pada hakekatnya menyajikan keterangan, catatan atau gambaran, baik untuk keadaan masa lalu, saat ini maupun masa yang akan datang bagi kelangsungan hidup perusahaan dan bagaimana efeknya pada perusahaan.

Perilaku investor sangat dipengaruhi oleh infomasi yang diterima. Hal ini menunjukkan bahwa individu menerima informasi dan merevisi keyakinan secara berurutan dalam proses berkelanjutan melalui penerimaan informasi yang terkandung dalam laporan keuangan dan juga dari sumber informasi lain seperti media, dan pengumuman lain yang dapat mempengaruhi keputusan investor (Puspitaningtyas, 2013).

Menurut (Lawrence A, 2009) Kepribadian adalah keseluruhan sikap, perasaan, ekspresi, tempramen, ciri-ciri khas dan perilaku seseorang. Sikap perasaan ekspresi dan tempramen ini akan terwujud dalam tindakan seseorang jika dihadapkan pada situasi tertentu. Setiap orang mempunyai kecenderungan prilaku yang baku, atau berlaku terus menerus secara konsisten dalam menghadapai situasi yang dihadapi, sehingga menjadi ciri khas pribadinya (Mehrani, Roodposhti, Nekomaram, \& Saeedi, 2016) mengemukakan bahwa sentimen investor adalah perasaan individu yang optimis atau pesimis yang berlebihan terhadap suatu situasi. Kedua definisi tersebut memberi tekanan pada faktor psikologis yakni keyakinan atau perasaan terhadap situasi tertentu.

Emiten adalah Pihak yang melakukan Penawaran Umum, yaitu penawaran Efek yang dilakukan oleh Emiten untuk menjual Efek kepada masyarakat berdasarkan tata cara yang diatur dalam peraturan Undang-undang yang berlaku. Jenis Efek yang lain adalah Sukuk, yang merupakan Efek Syariah, yakni akad dan cara penerbitannya sesuai dengan Prinsip Syariah di 
Pasar Modal. Pada umumnya, Emiten melakukan penawaran Efek melalui Pasar Modal untuk saham, obligasi, dan sukuk.

Menurut (Harahap, 2002) Profitabilitas (Profitability) adalah kemampuan perusahaan menghasilkan laba. Menurut (Sartono, 2010) Profitabilitas adalah Kemampuan perusahaan memperoleh laba dalam hubunganya dengan penjualan, total aktiva maupun modal sendiri. Dengan demikian bagi investor jangka panjang akan sangat berkepentingan dengan analisis profitabilitas ini misalnya bagipemegang saham akan melihat keuntungan yang benar-benar akan diterima dalam bentuk deviden.

company brand(Kotler, Philip, \& Armstrong, 2006) berpendapat bahwa merek merupakan istilah, tanda, nama, simbol, ataupun gabungan dari keseluruhannya yang digunakan untuk mengidentifikaskan barang atau jasa yang ditawarkan perusahaan kepada masyarakat juga langsung sebagai deferensiasi produk.

Keputusan investasi merupakan suatu kebijakan atau keputusan yang diambil untuk menanamkan modal pada suatu aset atau lebih untuk mendapatkan keuntungan di masa akan datang, atau bagaimana seseoranng mengalokasikan dananya kedalam macammacam investasi yang dapat menimbulkan keuntungan dimasa yang akan datang. Bentuk, macam dan komposisi dari investasi akan mempengaruhi dan menunjang tingkat keuntungan di masa depan (Wulandari, 2014).

Berdasarkan latar belakang yang telah tertera di atas, maka penelitian ini dilakukan untuk mengetahui pengaruh kepribadian,sentimen, probabilitas, dan company brand terhadap keputusan investor.

\section{METODE PENELITIAN}

Penelitian ini mengunakan pendekatan penelitian kuantitatif, untuk mengklasifikasikan penelitian ini, karena data yang digunakan dalam peneletian adalah berupa angka-angka dan pengelolahan datanya dan mengunakan statistik (Sugiono, 2009). Penelitian ini dilakukan di Kepulauan Riau. Waktu peneletian rencana dilakukan dari September 2018 hingga juni 2019.
Populasi pada penelitian ini adalah investor- investor yang ada diKepulauan Riau. Dikarenakan populasi pada penelitian ini merupakan yang bersifat infinitif, sehingga sampel yang akan digunakan untuk penelitian ini adalah purposive sampling dan dengan syarat minimal 100 responden pada suatu penelitian (JR, Black, Babin, \& Anderson, 2010)

Metode pengumpulan yang digunakan penelitian ini yaitu berdasarkan pembagian kuisioner secara online. Data kuisioner yang dikumpulkan akandilakukan pengujian pengujian validitas dan reliabilitas, untuk mengetahui validasi sama reliabilitas data yang dikumpulkan. Metode analisa penelitian yang digunakan adalah metode analisis regresi berganda, dengan mengunakan teknik analisis uji asumsi klasik untuk memenuhi syarat analisis regersi berganda.

\section{HASIL DAN PEMBAHASAN}

\section{Uji Validitas}

Suatu kuisioner dapat dikatakan sah jika pertanyaan pada kuisioner tersebut mampu mengungkapkan sesuatu yang diukur oleh kuisioner. Berdasarkan hasil uji validitas untuk semua pertanyaan dari semua varibel, setiap pertanyaan dinyatakan valid. Karena setiap item hasilnya $>0.05$.

\begin{tabular}{|c|c|c|c|}
\hline \multirow[t]{2}{*}{ Variabel } & \multirow{2}{*}{$\begin{array}{c}\text { But } \\
\text { ir }\end{array}$} & \multicolumn{2}{|c|}{ Hasil Uji Validitas } \\
\hline & & $\begin{array}{c}\text { Muatan } \\
\text { Faktor }\end{array}$ & Validitas \\
\hline \multirow[t]{3}{*}{ Kepribadian } & $\mathrm{K} 1$ & 0.787 & Valid \\
\hline & $\mathrm{K} 2$ & 0.827 & Valid \\
\hline & $\mathrm{K} 3$ & 0.793 & Valid \\
\hline \multirow[t]{2}{*}{ Sentimen } & $\mathrm{S} 1$ & 0.886 & Valid \\
\hline & $\mathrm{S} 2$ & 0.886 & Valid \\
\hline Profitabilitas & $\mathrm{P} 1$ & 0.765 & Valid \\
\hline
\end{tabular}




\begin{tabular}{llll}
\hline & P2 & 0.765 & Valid \\
Company & CB & 0.804 & Valid \\
Brand & 1 & & \\
& CB & 0.869 & Valid \\
& 2 & & \\
& CB & 0.735 & Valid \\
& 3 & & \\
& CB & 0.771 & Valid \\
Keputusan & 4 & & \\
Investor & KI1 & 0.789 & Valid \\
& KI2 & 0.847 & Valid \\
& & & \\
& KI3 & 0.809 & Valid \\
\cline { 2 - 4 } Sumber: & & & \\
\hline
\end{tabular}

\section{Uji Reliabilitas}

Uji Reliabilitas merupakan alat ukur kuisioner dari indikator variabel. Suatu kuisioner dikatakan reliable jika jawaban seseorang konsisten dan stabil dari waktu kewaktu. Reliabilitas diukur dengan uji statistik Cronbach Alpha. Suatu konstruk atau variabel dikatakan reliabel jika memberikan nilai Cronbach Alpha > 0,70 (Nunnally, 1994 dalam Ghozali, 2016) Hasil uji reliabilitas bisa dilihat pada tabel dibawah ini. Hasil uji reliabilitas penelitian ini adalah 0.865 dinyatakan reliabel.

Tabel 2. Hasil Uji Reliabilitas

\begin{tabular}{ll}
\hline Cronbach's Alpha & N of Item \\
\hline 0.865 & 14 \\
\hline Sumber: data SPSS yang diolah $(2019)$.
\end{tabular}

Sumber: data SPSS yang diolah (2019).

\section{Uji Normalitas}

Uji normalitas data penelitian ini dapat dilakukan dengan menggunakan One Sample Kolmogorov Smirnov yaitu dengan ketentuan jika nilai signifikan > 0,05 maka data terdistribusi normal. Jika nilai signifikan $<0,05$ maka data tidak terdistribusi normal.hasil pengujian adalah 0.665 lebih besar dari 0.05 maka model regersinya berdistribusi normal.
Tabel 3. One-Sample Kolmogorov-Smirnov Test

\begin{tabular}{lcl}
\hline & & $\begin{array}{l}\text { Unstandar } \\
\text { dized } \\
\end{array}$ \\
& & Residual \\
\hline $\mathrm{N}$ & & 122 \\
Normal & Mean & .0000000 \\
Parameters & Std. Deviation & .41144239 \\
Most $\quad$ ExtremeAbsolute & .066 \\
Differences $\quad$ Positive & .066 \\
\multicolumn{2}{l}{ Kolmogorov-Smirnov Z } & -.047 \\
Asymp. Sig. (2-tailed) & .727 \\
\hline
\end{tabular}

a. Test distribution is Normal.

b. Calculated from data.

\section{Uji Autokolerasi}

Model Regeresi yang bagus adalah model regresi yang bebas dari autokolerasi. Pada penelitian ini menguji autokolerasi dengan uji Durbin Waston. Hasil uji durbin waston adalah 1.839. nilai $\mathrm{DW}$ ini dibandingkan dengan nilai tabel yang nilai signifikan nya $5 \%$ dan jumlah 4 variabel bebas $(\mathrm{k}=4)$, jumlah sampel sebesar 122 $(n=122)$. Berdasarkan tabel Durbin Waston maka didapatkan nilai DL sebesar 1.6375, DU sebesar 1,7727, 4- DL sebesar 2.3625 dan nilai 4DU sebesar 2.2273. Maka nilai autokolerasi diantara 1.7727 < 1.839 ، 2.2273 jadi tidak terjadi autokolerasi.

Tabel 4. Model Summary ${ }^{b}$

\begin{tabular}{lllll}
\hline & \multicolumn{4}{c}{ Std. } \\
& $\mathrm{R}$ & \multicolumn{2}{c}{ Adjusted } & of \\
Model R & Square R Square & Estimate & Watson \\
\hline 1 & $.651^{\mathrm{a}} .424$ & .404 & .418 & 1.839
\end{tabular}

a. Predictors: (Constant), $\mathrm{x} 4, \mathrm{x} 1, \mathrm{x} 2, \mathrm{x} 3$

b. Dependent Variable: $y$

\section{Uji Multikolinieritas}

Pengujian multikolinierritas untuk menguji apakah adanya kolerasi antara variabel bebas. Hasil pengujian tidak terdapat multikol 
dalam model regersi, karena setiap variabel bebas nilai toleransinya lebih besar 0.10 dan nilai VIF lebih kecil dari 10. Hasil pengujian bisa dilihat pada tabel dibawah

Tabel 5. Hasil Uji Collinearity Statistic

\begin{tabular}{llc}
\hline Variabel & \multicolumn{2}{c}{ Collinearity Statistic } \\
& Tolerance & VIF \\
\hline $\mathrm{X} 1$ & 0.771 & 1.297 \\
$\mathrm{X} 2$ & 0.637 & 1.570 \\
$\mathrm{X} 3$ & 0.494 & 2.032 \\
$\mathrm{X} 4$ & 0.598 & 1.673 \\
\hline
\end{tabular}

Sumber: data SPSS yang diolah (2019)

\section{Uji Heteroskedastisitas}

Pengujian heteroskedastisitas pada penelitian ini mengunakan uji glejser. Hasil pengujian tidak terjadi heteroskedastisitas model regresi karena nilai untuk setiap variabel lebih dari besar 0.05 .

Tabel 6. Hasil Uji Glejser

\begin{tabular}{|c|c|c|}
\hline $\begin{array}{l}\text { Variabel } \\
\text { (constant) }\end{array}$ & $\begin{array}{c}T \\
2.308\end{array}$ & $\begin{array}{c}\text { Sig } \\
0.023\end{array}$ \\
\hline $\mathrm{X} 1$ & 1.772 & 0.079 \\
\hline $\mathrm{X} 2$ & -1.459 & 0.147 \\
\hline X3 & -0.517 & 0.606 \\
\hline $\mathrm{X} 4$ & 174 & 0.862 \\
\hline
\end{tabular}

Sumber: data SPSS yang di olah (2019)

\section{Hasil Uji F}

Pada tabel hasil uji $\mathrm{F}$ memperoleh nilai $\mathrm{F}$ sebesar 21.517 dan tingkat probabilitas 0.00 . tingkat probabilitas $0.00<0.05$ sehingga dapat disimpulkan kepribadian (X1), Sentimen (X2), Profitabilitas (X3), Company Brand (X4) secara simultan berpengaruh terhadap Keputusan Investor $(\mathrm{Y})$.

Tabel 7. Hasil Uji F

$\begin{array}{cccc}\begin{array}{c}\text { Variabel } \\ \text { Dependent }\end{array} & \text { F } & \text { Sig. } & \text { Kesimpulan } \\ \end{array}$

$\begin{array}{llll}\text { Keputusan } & 21.517 & 0.000 & \text { Signifikan } \\ \text { Investor } & & & \end{array}$

Sumber : data SPSS yang diolah (2019)

\section{Hasil Uji T}

Uji statistik $t$ pada dasarnya untuk menunjukan seberapa jauh pengaruh satu variabel independen secara individual dalam menerangkan variasi variabel dependent. Jika nilai signifikan $>0.05$ maka variabel independen bepengaruh terhadap variabel dependent. Sedangkan Jika nilai signifikan > 0.05 maka variabele independen tidak berpengaruh terhadap variabel dependent (Ghozali, 2013).

Tabel 8. Hasil Uji T

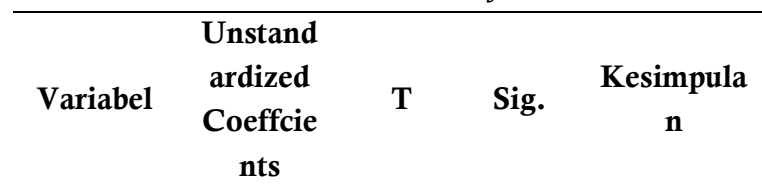

\begin{tabular}{lllll}
\multicolumn{5}{c}{ B } \\
\hline Constant & 0.517 & 2.531 & 0.013 & - \\
$\begin{array}{l}\text { Kepribad } \\
\text { ian (X1) }\end{array}$ & 0.113 & 1.351 & 0.179 & Tidak \\
& & & & Signifikan \\
$\begin{array}{l}\text { Sentimen } \\
\text { (X2) }\end{array}$ & 0.452 & 5.551 & 0.000 & Signifikan \\
$\begin{array}{l}\text { Profitabil } \\
\text { itas (X3) }\end{array}$ & -0.60 & - & 0.579 & Tidak \\
$\begin{array}{l}\text { Company } \\
\text { Brand }\end{array}$ & 0.260 & 2.704 & 0.008 & Signifikan \\
(X4) & & & & \\
\hline Sumber : data SPSS yang diolah (2019)
\end{tabular}

1. Tabel hasil uji T menunjukan bahwa tingkat signifikasi faktor kepribadian sebesar 0.179 lebih besar dari 0.05 sehingga variabel Kepribadian tidak berpengaruh signifikan terhadap keputusan investor.

2. Tabel hasil uji $\mathrm{T}$ menunjukan bahwa tingkat signifikansi Faktor Sentimen sebesar 0.00 lebih kecil dari 0.05 sehingga variabel Sentimen berpengaruh Signifikan terhadap keputusan investor.

3. Tabel hasil uji T menunjukan bahwa tingkat signifikansi Faktor profitabilitas Sebesar 0.579 lebih besar dari 0.05 sehingga Variabel profitabilitas tidak berpengaruh signifikan terhadap keputusan investor.

4. Tabel hasil uji $\mathrm{T}$ menunjukan bahwa tingkat signifikansi faktor company brand sebesar 0.008 lebih kecil dari 0.05 sehingga Varaibel 
company brand berpengaruh signifikan terhadap keputusan investor.

\section{Analisis Regersi Linier Berganda}

Tabel 9. Coefficients ${ }^{\mathrm{a}}$

\begin{tabular}{|c|c|c|c|c|}
\hline \multirow{5}{*}{$\begin{array}{l}\text { Model } \\
1 \text { (Constan }\end{array}$} & \multicolumn{4}{|c|}{ Standardize } \\
\hline & Unsta & ndardized & $\mathrm{d}$ & \\
\hline & Coeff & cients & Coefficients & \\
\hline & B & Std. Error & rBeta & Sig. \\
\hline & .517 & .204 & & 2.531 .013 \\
\hline $\mathrm{x} 1$ & .113 & .084 & .108 & 1.351 .179 \\
\hline $\mathrm{x} 2$ & .452 & .081 & .488 & 5.551 .000 \\
\hline $\mathrm{x} 3$ & -.060 & .108 & -.056 & -.556 .579 \\
\hline $\mathrm{x} 4$ & .260 & .096 & .245 & 2.704 .008 \\
\hline
\end{tabular}
diperoleh persamaan sebagai berikut:

$$
\begin{gathered}
\mathrm{Y}=0.517+0.113 \mathrm{X} 1+0.452 \mathrm{X} 2+-0.060 \mathrm{X} 3+ \\
0.260 \mathrm{X} 3+e
\end{gathered}
$$

Keterangan:

$\begin{array}{ll}\mathrm{Y} & \text { : Keputusan Investor } \\ \mathrm{a} & \text { : Nilai Konstanta } \\ { }_{1} 1-2 & \text { : Koefisiensi Deterninasi } \\ \mathrm{X} 1 & \text { : Kepribadian } \\ \mathrm{X} 2 & \text { : Sentimen } \\ \mathrm{X} 3 & \text { : Profitabilitas } \\ \mathrm{X} 4 & \text { : Company Brand } \\ e & \text { : Tingkat Kesalahan ( error) }\end{array}$

Berdasarkan persamaan diatas menjelaskan bahwa jika kepribadian investor mampu berinteraksi dan adaptasi dengan dunia pasar modal maka akan meningkat pengaruh terhadap keputusan investasi.jika informasi profitabilitas perusahan semakin transpasan maka akan menurunnya pengaruh keputusan investor dalam berinvestasi. Meningkatnya keyakinan dan harapan investor dalam berinvestasi dipasar modal maka akan meningkat pengaruh keputusan investor dalam berinvestasi. Meningkatnya informasi-informasi mengenai company brand maka akan meningkatnya pengaruh terhadap keputussan investor.

Tabel 10. Hasil Koefisien Determinasi

\begin{tabular}{ccccc}
\hline $\begin{array}{c}\text { Mo } \\
\text { del }\end{array}$ & R & $\begin{array}{c}\text { R } \\
\text { Square }\end{array}$ & $\begin{array}{c}\text { Adjusted } \\
\text { R Square }\end{array}$ & $\begin{array}{c}\text { Std. } \\
\text { Error of } \\
\text { the } \\
\text { Estimate }\end{array}$ \\
\hline 1 & 0.651 & 0.424 & 0.404 & 0.418 \\
& & & & \\
\hline
\end{tabular}

Sumber : data SPSS yang diolah (2019)

Berdasarkan hasil pengujian yang ditampilkan diatas bisa diketahui nilai Adjusted $R$ Square adalah 0.404 (40.4\%). Ini menyatakan bahwa Keputusan Investor (Y) dipengaruhi oleh Keperibadian (X1), Sentimen (X2), Profitabilitas (X3), Company Brand (X4) sebanyak 40.4\%. Sisanya (100\% - 40.4\%) 59.6\% dipengaruhi oleh variabel lainnya.

\section{Pembahasan}

Pada penelitian ini mengunakan data primer yang diperoleh dari kuisioner online yang di isi oleh investor-investor yang di pasar modal. Data yang berhasil dikumpulkan ada 122 responden. Karakteristik responden pada penelitian ini berdasarkan jenis kelamin, usia, pendidikan terakhir dan pekerjaan responden. Berdasarkan jenis kelamin kuisioner yang dikumpulkan responden wanita ada 65 responden dan pria ada 57 responden. Berdasarkan usia responden, yang dibawah 20 tahun ada 50 responden, usia diantara 21 sampai 30 tahun ada 69 responden, yang diantara usia 31 sampai 40 tahun ada 2 responden, serta yang diatas 40 tahun ada 1 responden. Berdasarkan pendidikan terakhir responden, tingkat SMK ada 54 responden dan tingkat S1,S2,S3 ada 68 responden. Berdasarkan pekerjaan responden, yang berkerja sebagai pengawai swasta ada 57 responden, bekerja sebagai wiraswasta ada 25 responden, yang sebagai mahasiswa ada 37 responden, yang sebagai siswa ada 2 responden, dan yang pengangguran ada 1 responden.

Pada penelitian ini menggunakan program SPSS versi 19. Hasil dari pengujian data menunjukan Adjusted $R$ Square adalah 0.404 
(40.4\%). Ini menyatakan bahwa keputusan investor dipengaruhi oleh keperibadian, sentimen, profitabilitas, dan company brand sebesar 40.4\%. Sisanya (100\%- 40.4\%) 59.6\% dipengaruhi oleh variabel lain. Variabel lainnya yang mungkin berpengaruh terhadap keputusan investor antara lain kondisi perekonomian Negara (Natapura, 2009), culture (Jalilvand et al., 2018), pendapatan dan pendidikan (Rahadjeng, 2011), psikologi pasar (Sundiman \& Septiani, 2017).

Pada hasil profil variabel nilai standar deviasi yang dihasilkan untuk setiap indikator pada semua variabel nilainya adalah mendekati nol, ini berarti tanggapan dari 122 responden besifat homongen dan memiliki keseragaman.

Pada Variabel kepribadian responden ratarata memilih setuju bahwa berinvestasi dipasar modal itu tidak mudah stress, tidak mudah khawatir dan merupakan tipe orang yang berani dalam mengambil risiko lebih banyak daripada pilihan lainnya. Pada variabel sentimen rata-rata responden menyatakan sangat setuju menpunyai rasa harapan yang tinggi berinvestasi di pasar modal daripada pilihan lainnya, dan rata-rata menyatakan setuju menpunyai keyakinan yang tinggi dalam berinvestasi di pasar modal dibandingkan pilihan lainnya.

Pada variabel profitabilitas rata-rata responden menyatakan setuju informasi profitabilitas perusahaan mudah didapatkan dan tingkat laba yang diharapkan dari saham cukup bagus dibandingkan variabel lainnya. Pada varibel company brand rata-rata responden menyatakan sangat setuju dengan memilih company brand yang cukup terkenal, reputasi pemegang saham yang cukup baik, dan mempunyai posisi yang meyakinkan di dunia industri. Dibandingkan dengan pilihan lainnya, serta responden rata-rata menyatakan setuju untuk memilih visi misi perusahaan mudah dipahami. Pada Varibel keputusan investor ratarata responden menyatakan sangat setuju akan rutin berinvestasi di pasar modal, baik sekarang maupun dimasa depan serta akan merkomendasikan orang-orang yang disekitarnya untuk berinvestasi di pasar modal daripada pilihan lainnya.
Berdasarkan hasil uji $\mathrm{F}$ dari olahan data SPSS versi 19 menyatakan bahwa model penelitian yang digunakan mampu memprediksi investor dalam pengambilan investasi, berarti variabel kepribadian, sentimen, profitabilitas dan company brand secara simultan berpengaruh terhadap variabel keputusan investor.

Pada hasil uji $t$ menunjukan bahwa variabel kepribadian memiliki nilai signifikan 0.179 lebih besar dari 0.05 , ini berarti variabel kepribadian tidak berpengaruh signifikan terhadap keputusan investor. Hasil ini tidak sesuai dengan Pendapat Liberty dan Spiegler pada penelitian (Saputri \& Pranata, 2014) mengatakan kepribadian merupakan cara hidup atau gaya keseluruhan tingkah laku individu. Variabel kepribadian tidak berpengaruh signifikan terhadap keputusan investasi diduga karena informasi perusahaan-perusahan di pasar modal tidak menampilkan profil risiko perusahaannya kepada investor-investor di pasar modal. Sehingga investor yang berani mengambil risiko maupun tidak berani mengambil risiko tidak berpengaruh signifikan terhadap keputusan investasi investor di pasar modal.

Berdasarkan hasil uji t pada penelitian ini menunjukan bahwa variabel sentimen berpengaruh positif terhadap keputusan investor, karena nilai signifikan adalah 0.000 lebih kecil dari nilai signifikan 0.05 . hal ini sesuai dengan pendapar (Mehrani et al., 2016) mengemukan bahwa sentimen investor adalah perasaan individu yang optimis atau pesimis terhadap suatu situasi.

Pada hasil uji $t$ menunjukan bahwa variabel profitabilitas memiliki nilai signifikan 0.579 lebih besar dari 0.05 . hasil ini tidak sesuai dengan pendapat yang di ungkapkan oleh (Hemastuti, 2014) Profitabilitas merupakan salah satu indikator yang penting untuk menilai suatu perusahaan. Variabel profitabilitas tidak signifikan terhadap keputusan investor diduga disebabkan oleh investor lebih mementingkan harga pergerakan pasar dan potensi dividen dalam pengambilan keputusan investasi. Ataupun investor kurang berpengalaman di pasar modal sehingga tampaknya investor tidak 
mampu menganalisa informasi keuangan perusahaan pada bagian profitabilitas yang didapat.

Berdasarkan hasil uji t variabel company brand berpangaruh positif terhadap keputusan investor, karena nilai signifikans varibel company brand adalah 0.008 lebih kecil dari 0.05. hasil ini sesuai dengan pendapat(Kotler et al., 2006)bahwa merek atau brand perusahaan merupakan istilah,tanda, nama atau pun gabungan keseluruhanya yang digunakan untuk mengidentifikasikan barang atau jasa kepada masyarakat.

\section{SIMPULAN}

Berdasarkan hasil pembahasanpembahasan pada bab sebelumnya maka dapat disimpulkan:

Variabel kepribadian tidak berpengaruh terhadap keputusan investor. karena perusahaan-perusahan di pasar modal tidak menampilkan informasi profil risiko perusahaannya kepada investor-investor di pasar modal. Sehingga investor yang berani mengambil risiko maupun tidak berani mengambil risiko tidak berpengaruh signifikan terhadap keputusan investasi investor di pasar modal.

Variabel sentimen berpengaruh positif terhadap keputusan investor. Hal ini berarti keyakinan dan harapan seorang investor dapat mempengaruhi investor dalam pengambilan keputusan investasi dipasar modal.

Variabel profitabilitas tidak berpengaruh terhadap keputusan investor. Berarti investor tidak memandang penting terhadap profitabilitas dalam pengambilan investasi, namun lebih mementing nilai-nilai lain seperti gerak harga saham ataupun potensi dividen dan sebagainya dalam pengambilan keputusan investasi di pasar modal.

Variabel company brand berpengaruh positif terhadap keputusan investor. Hasil ini berarti merek atau brand perusahaan merupakan istilah, tanda, nama atau pun gabungan keseluruhanya berpengaruh terhadap investor dalam pengmbilan investasi di pasar modal.

\section{DAFTAR PUSTAKA}

Ady, S. U., Sudarma, M., Salim, U., \& Aisyah, S. (2013). Psychology's Factors of Stock Buying and Selling Behavior in Indonesia Stock Exchange (Phenomenology Study of Investor Behavior in Surabaya). IOSR Journal of Business and Management, 7(3), 11-22. Retrieved from www.iosrjournals.org

Brigham, E. F., \& Houaton, J. F. (2001). manajemen keuangan. jakarta: Erlangga.

Chang, C. H., \& Lin, S. J. (2015). The effects of national culture and behavioral pitfalls on investors' decision-making: Herding behavior in international stock markets. International Review of Economics and Finance (Vol. 37). Elsevier Inc.

https://doi.org/10.1016/j.iref.2014.12.010

Ghozali, imam. (2013). Aplikasi Analisis Multivariate Dengan program IBM SPSS 21. Semarang: UNDIP.

Harahap, sofyan S. (2002). Analisis Kritis Atas Laporan PT.RajaGrafindo Persada (edisi 3). jakarta: PT.RajaGrafindo Persada.

Hemastuti, C. pami. (2014). Pengaruh Profitabilitas, Kebijakan Dividen, Kebijakan Hutang, Keputusan Investasi dan Kepemilikan Insider Terhadap Nilai Perusahaan. Jurnal Ilmu \& Riset Akuntansi, 3(4), 1-14.

Jalilvand, A., Rostami, M., \& Switzer, J. (2018). Journal of Economics and Business Informed and uninformed investors in Iran : Evidence from the Tehran Stock Exchange. Journal of Economics and Business, 95, 47-58. https://doi.org/10.1016/j.jeconbus.2017.08 .004

JR, J. F. H., Black, W. C., Babin, B. J., \& Anderson, R. D. (2010). Multivariate Data Analysis.

Kotler, Philip, \& Armstrong, G. (2006). Principles of Marketing (11th ed.). New york: Prentice Hall.

Lawrence A, P. (2009). Psikologi Kepribadian Teori dan Penelitian. yogyakarta: Graha Ilmu.

Mehrani, K., Roodposhti, F. R., Nekomaram, H., \& Saeedi, A. (2016). Behavioral trading strategies and investor sentiment: Empirical research in Tehran Stock Exchange (TSE). Indonesian Capital Market Review, 8(2), 94 109. https://doi.org/10.21002/icmr.v8i2.5708

Natapura, C. (2009). Analisis perilaku Investor Institusional dengan Pendekatan Analytical Hierarchy Process (AHP). Jurnal Ilmu 
Administrasi Dan Organisasi, 16(3), 180-187. https://doi.org/10.1016/j.foodres.2011.07. 033

Puspitaningtyas, Z. (2013). Perilaku Investor Dalam Pengambilan Keputusan Investasi Di Pasar, (December).

Rahadjeng, E. R. (2011). Analisis perilaku investor perspektif gender dalam pengambilan keputusan investasi di pasar modal, 6, 90-97.

Saputri, M. E., \& Pranata, T. R. (2014). Pengaruh Brand Image Terhadap Kesetiaan Pengguna Smartphone Iphone. Jurnal Sosioteknologi, 13(3), 193-201. Retrieved from http://journals.itb.ac.id/index.php/sostek/ article/view/1148/754.
Sartono, A. (2010). Manajemen Keuangan Teori dan Aplikasi (4th ed.). yogyakarta: BPFE.

Sugiono. (2009). metode penelitian bisnis (13th ed.). bandung: Alfabeta.

Sundiman, D., \& Septiani, H. (2017). Analisa Dampak Psikologi Pasar Terhadapa Harga Saham (IHSG) yang Terdaftar Di Bursa Efek Indonesia Dengan Metode Content Analysis. Jurnal Penerapan Ilmu Manajemen Dan Kewirausahaan, 2(1), 1-22.

Wulandari, D. A. (2014). Studi Experienced Regret, Risk Tolerance , Overconfidance, 4(1), 5566. 